\title{
The Awareness and Use of Electronic Learning Platforms: A Case of a Developing Country
}

\author{
Paul Nyagorme ${ }^{1}$, Albert Arthur Qua-Enoo ${ }^{1}$, Brandford Bervell $^{1,2, *}$, Valentina Arkorful ${ }^{1}$ \\ ${ }^{1}$ College of Distance Education, University of Cape Coast, Ghana \\ ${ }^{2}$ Centre for Instructional Technology and Multimedia, Universiti Sains Malaysia, Malaysia
}

Copyright $\bigcirc 2017$ by authors, all rights reserved. Authors agree that this article remains permanently open access under the terms of the Creative Commons Attribution License 4.0 International License

\begin{abstract}
E-learning is seen as a potent option for mass education globally. Consequently, institutions are hastily adopting it to meet the $21^{\text {st }}$ century education demands, often without recourse to considering the antecedents that promotes the success or otherwise of this mode of instruction. In view of this, the study investigates the awareness and use of e-learning platforms in some selected senior high schools in the Accra metropolitan area of Ghana with emphasis on parameters such as perception, training, accessibility, and infrastructural availability. Questionnaire was used to sample 303 respondents in this descriptive survey. Linear regression analysis and correlation were used on participants' training, motivation and computer availability in relation to perception, e-learning usage and awareness of e-learning implementation. The findings suggest participants know of e-learning and e-learning platforms but lacked adequate training. The computer literacy was low and most schools lacked adequate ICT laboratories and reliable internet negatively affects e-learning adoption. The major mode of internet access was the mobile phones. Students had a positive perception of e-learning and its adoption. The study recommends among other things that the Ghana Education Service train and educate teachers and students on e-learning to enhance their use and/or development of e-learning platforms. Furthermore, it should provide properly furnished ICT laboratories enhance accessibility and e-learning.
\end{abstract}

Keywords Awareness, Perception, Training, Infrastructure Availability, Accessibility, E-learning Usage

\section{Introduction}

The ubiquity and perversity of computers and their related accessories usage in every facet of human endeavors cannot be overemphasized. The rapidity, ease of usage and sophisticated integration of Information and Communication Technology (ICT) have placed an immense pressure on the major sectors of every country's economy such as commerce, education, manufacturing, law enforcement, banking, and culture. According to [18], future educational deliberations have become increasingly active with the feasibility of using digital textbooks and e-learning systems as information technology progress.

Policy makers realizing the huge potential benefits of ICT to meet the ever increasing complexities and dynamics of education are gradually integrating ICT to enhance their work in a concept called electronic learning (or e-learning). The Government of Ghana has developed a national framework policy document on ICT and educational integration called the Information Communications Technology for Accelerated Development (ICT4AD) to "...drive its information and knowledge-based economy and society” [37]. The efficiency and effectiveness of any organization depends on their Information Technology (IT) infrastructure. Evidence points to the fact that the services an institution can offer its relevant stakeholders is a direct function of its IT [21]. The prevalence and rapid development of ICT has transformed human society from the information technology age to the knowledge age [14].

The term e-learning has several definitions. "Reference [21]", defined e-learning as instruction delivered through purely digital technology, such as CD-ROMs, the Internet, or private networks. This definition centered on the technology viewpoint. According to [28], e-learning involves incorporating all educational activities that are carried out by individuals or groups working online or offline, and synchronously or asynchronously via network or standalone computers and other electronic devices. Thus e-learning includes, among other things, teaching and learning mediated by technology which with or without the timely presence of instructors and students. Furthermore, e-learning is sometimes synonymously referred to as virtual classroom, online learning, Web-Based Training, Computer-Based Training (CBT), and mobile learning.

The benefits of e-learning are enormous. These include cost-effectiveness; access to knowledge; social interaction; pedagogical richness; personal agency; and ease of revision 
[34]. However, the implementation of e-learning faces some challenges such as shortage of computers; outdated curricula; language adaptability issues; insufficiently trained teacher with low ICT skills; lack of electricity; expensive and slow Internet connectivity; and insufficient funding [2].

The strategic and systematic analysis, design, development, implementation and constant evaluation of e-learning in second cycle schools in Ghana can be used to minimize the above challenges in order to reap the benefits of e-learning. In the current study, the awareness and usage of e-learning platforms by senior high school students in the Accra metropolitan area of Ghana is analyzed to determine their perception, level of training, accessibility and adoption of e-learning.

The Government of Ghana, together with its developing partners and other stakeholders, over years has invested immensely in ICT in education. In spite of these laudable efforts, nothing substantial has changed in the schools as students are given much notes in manual form to memorize and reproduce. The awareness and utilization of e-learning websites and materials by teachers to promote innovative student-focused learning is lacking. Also there is the notion that computers are expensive and enigmatic equipment that must be delicately protected. This phenomenon tends to deter staff and students from actively engaging with computers to enhance their motivation in order to participate in e-learning. There is an uneven distribution of educational materials and properly qualified teachers when comparing urban and rural schools in Ghana. This inequality can be significantly bridged by e-learning. There is a yearly phenomenon of lack of access to secondary education by many Junior High School (JHS) graduates due to the low number of senior high schools in Ghana.

There have been many significant studies into the benefits of ICT in enhancing teaching and learning in the educational sector globally. However, current research seems to indicate that the mere presence of computers in the classroom does not necessarily translate into improved learning [8]. Critical analysis of teachers' and students' characteristics needs to be conducted to determine their awareness of e-learning platforms and whether they are actively using them to enhance their academic work. It is hoped that the study will unearth the current level of awareness and utilization of e-learning platforms in the Ghanaian senior high schools to enhance academic performance and address their deficiencies in computer literacy. Also, the high percentage of JHS graduates who do not gain secondary schools admission can be oriented to patronize these e-learning platforms as an alternative educational path to the tertiary institutions. Targeting these children is necessary for developing the human capital of the nation to fulfill the policy goal of ICT4AD. Furthermore, it is also hoped that the study will assist Ghana education policy-makers identify challenges or opportunities in their quest for quality secondary education that is accessible to all children throughout the country.
The focus of the study was to address the following questions

- What is the perception of students and teachers towards the use of e-learning platforms?

- How accessible is the Information Technology (IT) infrastructure to students?

- What is the level of e-learning training that the staff and students possess?

- How accessible are the e-learning platforms to the students during non-teaching hours?

\section{Research Hypotheses}

The study sought to find answers to the following research hypotheses:

- $\mathrm{H}_{0}$ : Online duration is independent of e-learning usage

- $\mathrm{H}_{1}$ : Online duration is independent of e-learning usage

\section{Correlation}

- H2: Training has a relationship with motivation.

- H3: Training has a relationship with perception.

- H4: Training has a relationship with use.

- H5: Availability has a relationship with motivation.

- H6: Availability has a relationship with use.

- H7: Motivation has a relationship with perception.

- H8: Motivation has a relationship with use.

- H9: Perception has a relationship with use.

\section{Regression}

- H10: Training predicts motivation.

- H11: Training predicts perception.

- H12: Training predicts use.

- H13: Availability predicts motivation.

- H14: Availability predicts use.

- H15: Motivation predicts perception.

- H16: Motivation predicts use.

- H17: Perception predicts use.

\section{Review of Relevant Literature}

E-learning exists in many forms. To understand the various form of e-learning, [36] identified four e-learning modalities (individualized self-paced e-learning offline, individualized self-paced e-learning online, Group-based e-learning asynchronously and Group-based e-learning synchronously). This study focuses mainly on the first and third modalities which involve an individual or a group of learners using the internet as the medium of instructional delivery. The perception, training, accessibility, and adoption of e-learning were the parameters employed by the researcher in investigating the awareness and utilization of e-learning platforms by senior high schools.

E-learning perception. Perception denotes a belief or opinion, often held by people and based on appearances. The 
perception of e-learning by stakeholders of educational institution varies. The role of technology in education has been immensely debated on during the last quarter of the $20^{\text {th }}$ century with the popular debate between Clark [9] and Kozma [20]. Whiles Clark [9] argued that media will never influence learning [9], Kozma [20] countered that capabilities of a particular medium cum methods that can take advantage of these capabilities will ultimately influence learning [20]. Personal experiences have impact on e-learning usage. The dominant learning theory in the Ghana senior high school is behaviorism where the teacher is seen as a "sage on the stage". Instruction is unidirectional proceeding from the teacher to the learner and instructional material is content-focused instead of student-centered. E-learning has the potential to elicit student interaction, critical thinking, enhance student motivation and provide situated learning environment through stimulation. Confidence and perception of instructors affect the learning capabilities of students according to [12].

E-learning Training. Training is critical to successful implementation. The successful use of ICT in education depends on teacher's skills in integrating ICT into pedagogy and in utilizing ICT to provide learner-centered interactive education [39]. The benefits of training in e-learning include ready acceptance, increased performance, reduction of barriers and transforming traditional academic institutions into $21^{\text {st }}$ century schools where teachers become facilitators instead of sources of knowledge. Sufficient training on e-learning platforms will invariable result in high confidence, excitement and commitment to e-learning engagement. "Reference [41]", supported this assertion by indicating that "inadequate or incomplete knowledge and awareness inevitably compromises the quality and appropriateness of learning experiences which can be provided and developed". Most teachers and students in third world countries have limited computer skills and therefore face challenges in using e-learning. Also, the absence or scarcity of e-learning training for educational policy makers, administrators, and teachers serves as a great disincentive to e-learning integration. There is a wrong perception in Ghana that e-learning equates classroom with computers and therefore follow the same behavioral instructional method. Teachers must first be trained as e-learners before a successful e-learning educational setting can be actualized.

E-learning Availability and Accessibility. The World Wide Web has seen an enormous transformation due to the development of social software technologies such as twitter, YouTube, slideshare, Picasa, media wiki, weblogs, mobile e-learning applications, and Facebook. These web tools help students to enjoy learning autonomy and self-management, improve their metacognition, high retention of information and interactivity during the learning process. However, these benefits are highly dependent on the availability and accessibility of IT facilities to students at both home and school. The relative use of internet at home and at school is also important to the awareness and use of e-learning. The accessibility of the IT facilities within the portions of the school and community such as classroom, libraries, dormitories, and internet cafés, need to be looked into to ensure smooth interaction between learners and content. The International Society for Technology and Education (ISTE) has standards for students, teachers, and administrators. With reference to teachers (Annex 5) as cited by [31], teachers should: facilitate and inspire student learning and creativity; design and develop digital-age learning experience and assessments; model digital-age work and learning; promote and model digital citizenship and responsibility; and engage in professional growth and leadership.

E-learning Adoption. The immense benefits of E-Learning have motivated employees, students and organizations to adopt E-Learning [17]. They noted that while the percentage of America's organizations using E-Learning rose from $8 \%$ in 1999 to $29 \%$ in 2006, there is still a great challenge in persuading an organization to accept advanced internet technologies. The presence of e-learning tools available to school does not necessarily imply acceptability and integration. According to [13], several factors such as socio-cultural, organizational, intra- and interpersonal character, fear of computer threats and the lack of trust in securing sensitive data, are at play when adopting e-learning. In analyzing the barriers to E-Learning adoption, [3] noted that the threats, challenges, and losses brought by technology were typically less discussed. Also increase awareness and understanding the overall nature of issues experienced by e-learning justify the critical examination of the heavy investments, promises, and exponential growth associated with e-learning. As indicated earlier, the rate of e-learning adoption by an individual is largely dependent on prior utilization of e-learning tools. The success of e-learning adoption is also dependent on well-researched study of activities which include the full integration of e-learning into the curriculum, textbooks and tests; a strong program of training teachers to both use and teach with technologies; the establishment of a pedagogical foundation for e-learning to assist teachers in integrating it into their teaching; providing ongoing support for teachers; and educators joining a community of practice.

Motivation. Motivation plays an important element in the online learning environment. According to [24] a, motivation is a 'hypothetical construct that broadly refers to those internal and external conditions that influence the arousal, direction, and maintenance of behaviour. Constructivist's learning theory of e-learning requires students to be active learners, critical thinkers, self-starters and creative actively developing their own knowledge. According to [9] an e-learner may be seen as someone who is independent and self-motivated, and as having a positive attitude to learning and the ability to collaborate and cooperate with fellow learners. "Reference [30]" noted that the role of motivation in the online learning environment is due to the assumption that e-learners are self-motivated and 
active learners. In the Keller ARCS model the concepts of attention (A), relevance(R), confidence (C), and satisfaction (S) is stresses in motivating e-learning students. Other motivational factors involves personal relevance and interest; choice and control; and sense that one can master the material [4].

\section{Methodology}

The descriptive survey design was used for student. This design investigates the incidence, distribution and interrelations among sociological, psychological and educational variables as it collects data for the purpose of testing hypothesis or answering prevailing questions concerning the current position of the subject under study; and aims at determining and reporting how things look like with respect to established theories or assumptions on the subject [12]. The researchers applied correlation analysis, ANOVA and linear regression to investigate interactions among the variables being studied. The model below would be explored.

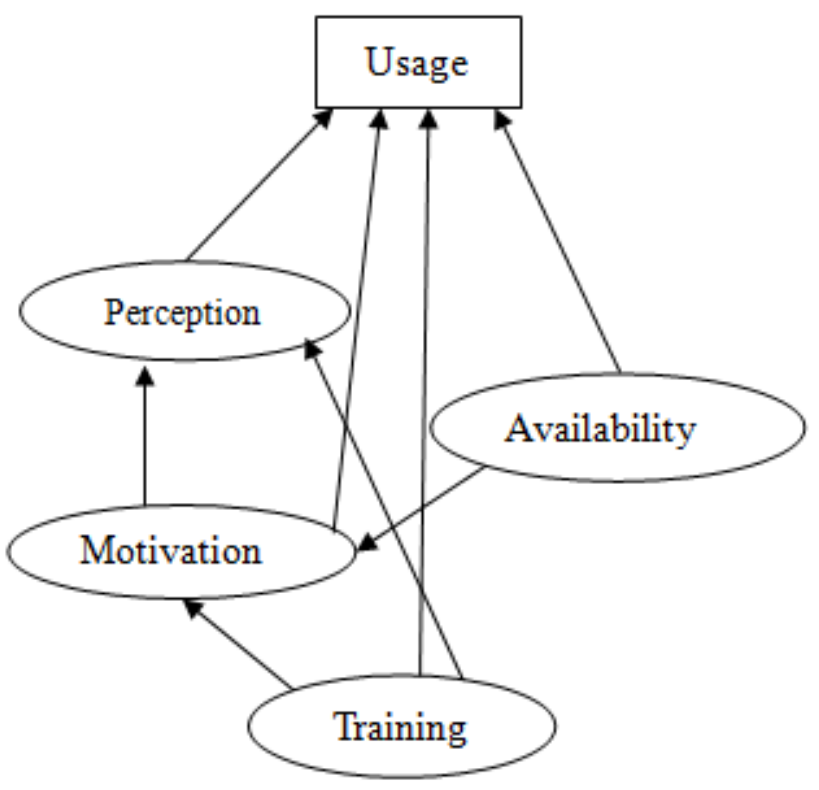

Figure 1. Proposed E-learning usage model

Participants. Questionnaires were used to elicit information from a sample of 303 respondents from a population of 10569 in this descriptive survey. The cluster sampling method was employed to select the schools and the simple random sampling method used to select the participants. For students, it was based on the students' register while the staff attendance book was used to select the staff. Of the participants, $49.3 \%$ were females $(n=148)$ and $50.7 \%$ male $(\mathrm{n}=152)$ with $0.9 \%(\mathrm{n}=3)$ participants failing to state their gender. In terms of school membership, 10.5\% were staff $(n=31)$ and $89.5 \%$ students $(n=264)$. The age group of the participants ranged between 15 - 60 years with the average age group being $15-19$ years. The participants came from six senior high schools (SHS) as follows: Accra Girl's SHS - 39 (13.2\%), Christian IPS - 64 (21.7\%), Holy Trinity Cathedral SHS - 11 (3.7\%), New Star S. H. T. S. - 35 (11.9\%), Odorgonnor SHS - 37 (12.5\%), and St. John's Grammar SHS - 109 (36.9\%). 8 (0.1\%) participants did not start their school.

An online survey was the main instrument for this study. The students were sampled from the five major program option: General Arts $-65.8 \%$, Business $-20.4 \%$, Science $10.8 \%$, Visual Arts $-2.5 \%$, and Agricultural Science $-0.4 \%$. More than half of the participants (70.6\%) reported that they own a computer (i.e. desktop, laptop, tablet, mobile phone).

\section{Results of the Study}

This study analyzed self-reported opinions and perceptions of Ghanaian senior high school students and staff concerning awareness and usage of e-learning platforms. The main e-learning factors considered in this study are demographics, computer skills, e-learning perception, e-learning training, e-learning accessibility, e-learning adoption and the patronage of e-learning platforms duration.

Table 1. Computer Skills

\begin{tabular}{|c|c|c|}
\hline Response & Frequency & Percentage (\%) \\
\hline Yes & 231 & 77.0 \\
\hline No & 69 & 23.0 \\
\hline Total & 300 & 100.0 \\
\hline
\end{tabular}

Table 1 shows information about investigation into the computer literacy/skills of respondents prior to joining their current institution. $77.0 \%$ were computer literate whiles the 23.0\% had no skills in computer usage.

\section{Access Device Distribution}

Table 2. Access Device Distribution

\begin{tabular}{|c|c|c|}
\hline Response & Frequency & Percentage (\%) \\
\hline Mobile phone & 125 & 41.4 \\
\hline USB Modem & 58 & 19.2 \\
\hline School's Internet & 39 & 12.9 \\
\hline Internet Café & 67 & 22.1 \\
\hline No internet Access Device & 13 & 4.3 \\
\hline Total & 303 & 100.0 \\
\hline
\end{tabular}

Alternatively, the smart phone was the most common means of online access (41.1\%), followed by the Internet café (22.2\%), the universal serial bus (USB) modem (common called personal modem) came third (19.1\%) with the school internet been the least used mode. $4.5 \%$ had no internet access device as Table 2 shows. 
Table 3. Awareness of Electronic-learning platforms

\begin{tabular}{|c|c|c|}
\hline Response & Frequency & Percentage (\%) \\
\hline Yes & 224 & 75.4 \\
\hline No & 73 & 24.6 \\
\hline Total & 297 & 100.0 \\
\hline
\end{tabular}

In Table 3, the study showed that 297 out of 303 respondents answered the question on whether they have heard of e-learning or not. $75.4 \%$ answered in the affirmative and $24.6 \%$ answered in the negative.

Table 4. Heard of E-Learning

\begin{tabular}{|c|c|c|}
\hline Response & Frequency & Percentage (\%) \\
\hline Yes & 224 & 75.4 \\
\hline No & 73 & 24.6 \\
\hline Total & 297 & 100.0 \\
\hline
\end{tabular}

In Table 4, the study showed that 297 out of 303 respondents answered the question on whether they have heard of e-learning or not. $75.4 \%$ answered in the affirmative and $24.6 \%$ answered in the negative.

Table 5. Used E-Learning Platform

\begin{tabular}{|c|c|c|}
\hline Response & Frequency & Percentage (\%) \\
\hline Yes & 89 & 29.8 \\
\hline No & 210 & 70.2 \\
\hline Total & 299 & 100.0 \\
\hline
\end{tabular}

The Table 5 above showed that although majority of the respondents (70.2\%) had heard the word e-learning, less than thirty percent (29.8\%) of them had used e-learning platforms prior to the survey.

Table 6. Received Training on E-Learning Platforms before joining School

\begin{tabular}{|c|c|c|}
\hline Response & Frequency & Percentage (\%) \\
\hline Yes & 46 & 16.0 \\
\hline No & 241 & 84.0 \\
\hline Total & 287 & 100.0 \\
\hline
\end{tabular}

The low patronage of e-learning platforms was not a surprise due to the fact that only $16.0 \%$ of the respondents had received training in e-learning before becoming members of their present institutions according to the Table 6 above. $84.0 \%$ hand no training in e-learning.

Table 7. Preference for Online Academic Discussions

\begin{tabular}{|c|c|c|}
\hline Response & Frequency & Percentage (\%) \\
\hline Yes & 286 & 95.3 \\
\hline No & 11 & 3.7 \\
\hline Not Sure & 3 & 1.0 \\
\hline Total & 300 & 100.0 \\
\hline
\end{tabular}

In the Table 7 above, an overwhelming 95.3\% of the respondents favored e-learning with other colleagues and staff. Also, very few respondents (3.7\%) did not favor e-learning while only $1.0 \%$ of the respondents indicated note sure.

Table 8. Motivation for Electronic Learning

\begin{tabular}{|c|c|c|}
\hline Response & Frequency & Percentage (\%) \\
\hline Low & 12 & 4.0 \\
\hline Medium & 86 & 28.6 \\
\hline High & 113 & 37.5 \\
\hline Very high & 90 & 29.9 \\
\hline Total & 301 & 100.0 \\
\hline
\end{tabular}

The Table 8 above gave a further insight into how motivated respondents were concerning E-Learning usage: only $4.0 \%$ had low motivation; $28.6 \%$ had medium motivation; 37.5\% had high motivation; and 29.9\% had very high motivation.

Table 9. Total E-Learning Perception Frequency

\begin{tabular}{|c|c|c|}
\hline Response & Frequency & Percentage (\%) \\
\hline Strongly Agree & 83 & 27.5 \\
\hline Agree & 107 & 35.3 \\
\hline Not Sure & 54 & 17.9 \\
\hline Disagree & 34 & 11.2 \\
\hline Strongly Disagree & 24 & 8.0 \\
\hline Total & 303 & 100.0 \\
\hline
\end{tabular}

The Table 9 above investigated the aggregate perception of respondents about e-learning. Out of the 303 respondents: $27.5 \%$ indicated strongly agree; $35.3 \%$ stated agree; $17.9 \%$ specified not sure; $11.2 \%$ stated disagree; and $8.0 \%$ showed that they strongly disagreed with use e-learning. 


\section{Confidence in E-learning}

Table 10. Respondents' Confidence in E-Learning

\begin{tabular}{|c|c|c|c|c|c|c|}
\hline Perception & $\begin{array}{l}\text { SA } \\
\text { (\%) }\end{array}$ & $\begin{array}{c}\text { A } \\
(\%)\end{array}$ & $\begin{array}{l}\text { N S } \\
\text { (\%) }\end{array}$ & $\begin{array}{c}\mathrm{D} \\
(\%)\end{array}$ & $\begin{array}{l}\text { S D } \\
\text { (\%) }\end{array}$ & $\begin{array}{c}\text { Total } \\
(\%)\end{array}$ \\
\hline E-Learning Platforms Provide Better Learning Experience & 39.3 & 47.5 & 9.2 & 4.0 & 0.0 & 100 \\
\hline E-Learning Platforms Enhance Better Understanding of Content & 25.4 & 46.9 & 23.1 & 3.3 & 1.3 & 100 \\
\hline E-Learning Platforms Are Useful For Students’ Assessment & 35.0 & 43.6 & 18.2 & 3.6 & 1.7 & 100 \\
\hline E-Learning Platforms Make Teaching More Interesting & 38.9 & 46.5 & 10.9 & 3.3 & 0.0 & 100 \\
\hline E-Learning Platforms Are Simple And Easy To Use & 35.3 & 41.3 & 18.8 & 3.6 & 1.0 & 100 \\
\hline Do Not Want To Have Anything To Do With E-Learning Platform & 3.6 & 6.9 & 10.2 & 36.7 & 33.2 & 100 \\
\hline IT Intimidates Me & 8.3 & 13.9 & 14.2 & 33.3 & 30.4 & 100 \\
\hline E-Learning Platforms Can’t Improve Students’ Academic work & 7.9 & 12.5 & 9.9 & 32.0 & 37.6 & 100 \\
\hline Inaccessibility To ICT Facilities Discourages my Use of E-Learning & 24.4 & 37.0 & 12.2 & 13.9 & 12.5 & 100 \\
\hline E-Learning Discourages Students From Using Textbooks & 9.9 & 27.7 & 17.5 & 26.1 & 18.8 & 100 \\
\hline There Is Reliable Internet For Using E-Learning Platforms & 18.2 & 37.6 & 26.1 & 12.5 & 5.6 & 100 \\
\hline The School ICT Lab Is Adequate For The Use Of E-Learning Tools & 18.2 & 25.1 & 23.1 & 13.2 & 20.5 & 100 \\
\hline There Is Sufficient Administrative Support For E-Learning & 20.5 & 36.3 & 18.2 & 12.9 & 12.2 & 100 \\
\hline E-Learning Content Are Suitable For SHS Students & 32.0 & 40.0 & 22.8 & 3.0 & 1.3 & 100 \\
\hline E-Learning Platform Content Is Ethically Bias Or Offensive & 5.9 & 7.9 & 31.0 & 30.0 & 25.1 & 100 \\
\hline E-Learning Platform Provides Adequate Support Systems & 33.3 & 40.9 & 21.5 & 1.0 & 3.3 & 100 \\
\hline
\end{tabular}

Table 10 above displays data about respondents' perception of e-learning platforms. 47.5\% agreed that e-learning platforms provide better learning experience. Also, $44.9 \%$ agreed that e-learning platforms enhance better understanding of content. Similarly, $44.2 \%$ agreed that e-learning platforms are useful for the assessment of students. Likewise, 46.5\% agreed that e-learning platform make teaching more interesting. Also, 41.3\% agreed that e-learning platforms are simple and easy to use. However, $36.7 \%$ disagreed that they did not have anything to do with e-learning platforms. According to [16], increased anxiety towards computers tends to invoke negative attitude towards them. Similarly, 33.3\% disagreed that the use of IT intimidated them. Meanwhile, 37.6\% strongly disagreed that e-learning cannot improve students' academic performance. $37.0 \%$ agreed that inaccessibility to ICT facilities discourages their use of e-learning. Similarly, 27.7\% agreed that E-Learning discourages students from using textbooks.

Likewise, $37.6 \%$ agreed that there is reliable internet for using e-learning platforms. In the same way, $25.1 \%$ agreed that the school ICT laboratory was adequate for the use of e-learning tools.

Similarly, $36.3 \%$ of the respondents agreed that there is sufficient administrative support for e-learning. Likewise, $40.0 \%$ agreed contents of the e-learning platforms are educationally suitable.

Meanwhile, 31.0\% were not sure that e-learning platform content is ethically bias or offensive. Finally, 40.9\% agreed that e-learning platform provides adequate feedbacks and help support systems.

\section{Correlation Analysis}

In analyzing the relationship between the e-learning usage, training, motivation, and perception matrix the p-values were used to test the hypotheses in Table 11 with a significant level $\alpha=0.05$. Table 11 indicated that there were statistically significant linear relationships between training and perception and E-learning usage; availability of IT infrastructure and motivation; and E-learning usage and motivation. However, there were no statistically significant linear relationship between training and motivation; IT infrastructure availability and E-leaning usage; motivation and perception; and perception and E-learning usage.

Table 11. Summary of Correlation Coefficients and P-value

\begin{tabular}{|c|c|c|}
\hline & $\begin{array}{c}\text { Pearson Correlation } \\
\text { Coefficient }\end{array}$ & $\begin{array}{c}\text { Sig. } \\
\text { (1-tailed) }\end{array}$ \\
\hline Training verses Motivation & 0.032 & 0.291 \\
\hline Training verses Perception & 0.123 & $0.016^{*}$ \\
\hline Training verses Usage & 0.154 & $0.004^{*}$ \\
\hline Availability verses Motivation & 0.192 & $0.000^{*}$ \\
\hline Availability verses Usage & 0.053 & 0.178 \\
\hline Motivation verses Perception & 0.094 & 0.051 \\
\hline Motivation verses Usage & 0.133 & $0.010^{*}$ \\
\hline Perception verses Usage & 0.090 & 0.059 \\
\hline
\end{tabular}

$\mathrm{p}<0.05, *$ indicates significant values 
Table 12. Summary of ANOVA and Regression Coefficient

\begin{tabular}{|c|c|c|c|c|c|}
\hline & \multicolumn{2}{|c|}{ ANOVA } & \multicolumn{3}{c|}{ Regression } \\
\hline & $\mathrm{F}$ & $\mathrm{Sig}$ & Coefficient & $\mathrm{t}$ & $\mathrm{p}$-value \\
\hline Training predicts Motivation & 0.302 & 0.583 & 0.040 & 0.550 & 0.583 \\
\hline Training predicts Perception & 4.563 & 0.033 & 0.150 & 2.144 & $0.033^{*}$ \\
\hline Training predicts Usage & 7.266 & 0.007 & 0.040 & 2.696 & $0.007^{*}$ \\
\hline Availability predicts Motivation & 11.468 & 0.001 & 0.312 & 3.386 & $0.001^{*}$ \\
\hline Availability predicts Usage & 0.854 & 0.356 & 0.089 & 0.924 & 0.356 \\
\hline Motivation predicts Perception & 2.687 & 0.102 & 0.180 & 1.639 & 0.102 \\
\hline Motivation predicts Usage & 5.411 & 0.021 & 0.136 & 2.326 & $0.021^{*}$ \\
\hline Perception predicts Usage & 2.467 & 0.117 & 0.177 & 1.571 & 0.117 \\
\hline $\mathrm{P}<0.05, *$ indicate significant values & & & & \\
\hline
\end{tabular}

\section{Regression Analysis}

Regression analysis was used to determine how well the variables (training, motivation, infrastructure availability, and perception) predict the usage of e-learning platforms by the respondents in Table 12. Also, the effect training and motivation have on respondents' perception of e-learning platforms was explored. Furthermore, the roles of training and IT infrastructure availability in motivating respondents' use of e-learning were analyzed. The confidence interval was 95\%. Training was found to statistically predict E-learning perception and E-learning usage but did not significantly predict motivation. Also, IT infrastructure availability statistically predicted motivation but failed to predict E-learning usage. Motivation statistically predicted E-learning usage but could not significantly predict E-learning usage. Finally, perception did not statistically predict E-learning.

\section{Discussion}

\section{Research Question 1}

What is the perception of students and teachers towards the use of e-learning platforms?

Although the majority of the respondents had heard of the word e-learning (75.4\%) and most of them had limited knowledge in the use of e-learning platforms (70.2\%), there was an over whelming support for the use of e-learning platform (95.3\%). This perception was attested by the fact that 289 respondents representing $96.0 \%$ of the total survey had medium to very high motivation for e-learning.

The general view of respondents on e-learning was favorable. The application of IT into the sectors of the economy and aspects of life has led to massive improvement in productivity and ease of living respectively. By application, it is also perceived that the integration of IT into education will be beneficial. Thus, almost ninety percent (86.3\%) held that e-learning platforms can provide enhanced student learning experience through the presentation of content through different media to gain better understanding (72.3\%); objective and quicker assessment of learners (78.6\%); and e-learning websites are simple and easy to use (76.6\%).

The study also found out that there was also the general consensus that the contents of most e-learning websites sufficiently covered the required syllabi of senior high schools in Ghana (72.0\%); the learning websites did not contain racial, rude, sexual explicit or any offensive content that can be inimical to the morals and ethics of the students (55.1\%). Finally, the high acceptance of e-learning platforms was enhanced by the adequate feedbacks and help support systems they provide for the customers which were found to be $74.2 \%$.

\section{Research Question 2}

How accessible is the IT infrastructure (computers and internet facilities) to students?

The second task was to find out how accessible was the IT infrastructure (computers and internet facilities) to students. The overall observation was that accessibility to IT infrastructure was major issue. The findings from the study revealed $61.4 \%$ of the respondents stated that the inaccessibility of IT facilities discourage them from patronizing e-learning. Reference [43]” noted that access to technological resources is an effective way to teachers' use of e-learning. This situation was confirmed by the fact that almost sixty percent (56.8\%) of them disagreed or were not sure that their school ICT laboratories were adequately stuffed with resources for the usage of e-learning tools. This phenomenon was in agreement with a study by [28] report as cited by [1] which showed that about $78 \%$ of the respondents complained of inadequate access to computers in their schools. According to [35], adequate hardware, software, and media are vital conditions for effective use of technology. Furthermore, although the majority of the respondents (70.6\%) possessed computers, the greater part of the type of computer was mobile phones. This was attested to by the fact that mobile phones were the key device (41.4\%) for 
accessing the Internet. Most of the mobiles in Ghana are imitated ones due to the high price of the genuine ones, heat up when used for a longer time, and has low battery life span. Also, the internet service provided by the mobile telecommunication networks is of poor quality with frequent loss of signal and high price tariffs. It should also be noted that most senior high schools have small ICT laboratories and virtual no Wi-Fi facilities fact that the use of mobile phones is banned in coupled with the fact that the use of mobile phones is banned in these schools.

The internet cafés are not as ubiquitous as one will expect and services they render is poor with slow internet connectivity and frequently patronized by internet fraudsters popularly called "sakawa” or " 419 " in Ghana. Therefore, some parents have barred their wards from internet cafés with the fear that they may be influenced by these fraudsters.

\section{Research Question 3}

What is the level of e-learning training that the staff and students possess?

The third task was tackling the level of e-learning training that both staff and students have undergone. The majority of the respondents $(84.0 \%)$ had no training in the use of e-learning platforms. "Reference [25]" observed that a higher level of computer experience is linked to greater enjoyment of users with Web-based learning. The lack of training to enable greater exposure could also account for the reason why the respondents spend a large percentage (72.0\%) of their online access on social networking sites (facebook.com,whatsapp.com, instagram.com, snapchat.com, viber.com, etc.), informational sites, sports sites and video sharing sites combined. This phenomenon is an immense contributing factor to the low patronage (70.2\%) of e-learning in the schools [7]. In the era of globalization and democratization in learning, the sourcing of knowledge worldwide is imperative to the competitive advantage of the institution and the creation of very good products of the school system. [27], noted that technology training is necessary for successful integration of technology in the classroom.

\section{Research Question 4}

How accessible are the e-learning platforms to the students during non-teaching hours?

The fourth task looked at the accessibility to e-learning platforms by respondents and by extension the availability or internet access to them during non-teaching periods. 91.2\% had access to the internet during non-teaching periods and this is mostly non-residential students. This observation was also made by [41]. Due to the ban and seizure of mobile phones in senior high schools, it can be assumed that the internet/e-learning platform access was solely non-teaching hours. By the rules and regulations of most SHS, students are not allowed to use electrical gadgets in schools. Boarding house students, therefore, do not have access to any internet access unless on vacations. The scarcity of opportunity to use computers is a reason why students and teachers were slow to ICT integration as noted by [5].

The other alternative was to use the school ICT laboratory after normal school hours, but that is also unlikely because the ICT staff members are non-resident on the campuses and the current erratic power situation the country is facing. This restriction by the when they need to combined them with classroom work.

\section{Research Hypotheses}

What is the relationship between online duration and E-Learning usage?

The study sought to determine whether the significant amount of time is used by the respondents to access e-learning websites when they go online. The results from Table 13, it was observed that respondents spent a large percentage of their online hours on other sites instead of e-learning websites. Also, we fail to reject the null hypothesis $\left(X^{2}=7.721, \mathrm{df}=8, \mathrm{p}>0.05\right)$. There is not enough evidence to suggest that any difference between online hours and e-learning platform usage by respondents is for any reason other than chance (e.g. sampling error, etc.). Thus there is no statistically significant relationship between the number of hours respondents spent on the internet and the patronage of e-learning websites.

Table 13. Chi-Square Tests

\begin{tabular}{|c|c|c|c|}
\hline & Value & $\mathrm{df}$ & Asymp. Sig. (2-sided) \\
\hline Pearson Chi-Square & $7.721^{\mathrm{a}}$ & 8 & .461 \\
\hline Likelihood Ratio & 9.851 & 8 & .276 \\
\hline Linear-by-Linear Association & 4.726 & 1 & .030 \\
\hline N of Valid Cases & 294 & & \\
\hline
\end{tabular}

a. 7 cells $(38.9 \%)$ have expected count less than 5 . The minimum expected count is 0.71 .

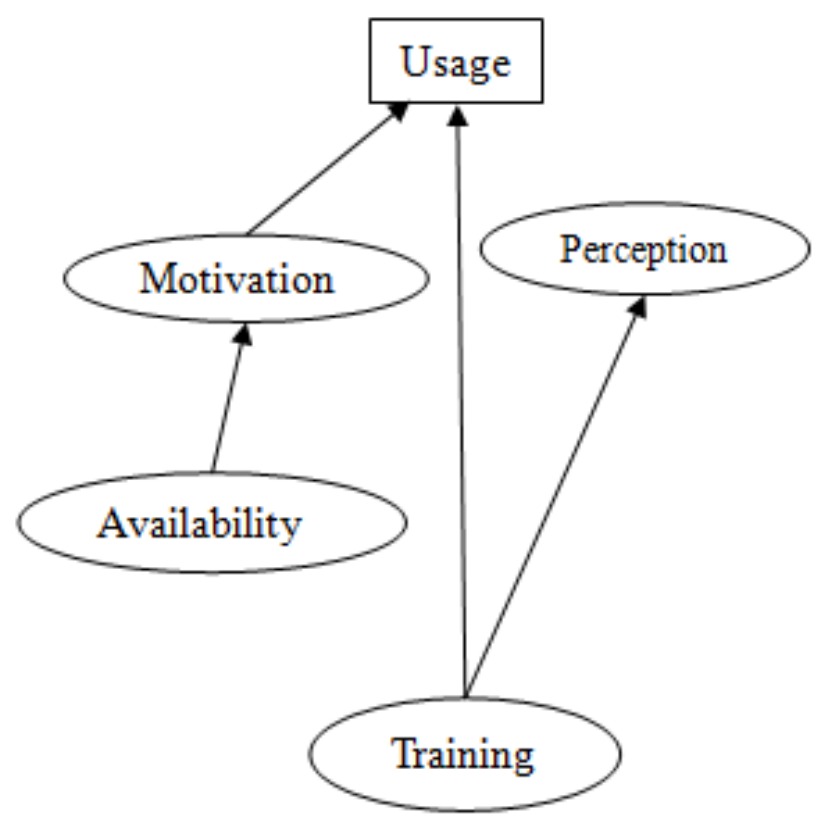

Figure 2. Final E-learning usage model 
The significant relationship established between training and perception as well as utilization implies that provision of E-learning tools must be backed by a systematic training.

According to [37], comprehensive training greatly influences attitude to computer integration by eliminating anxiety, lack of confidence/competence and fear. It therefore implies that the absence or a poorly designed E-learning training result low motivation. Improper integration of E-learning can lead to abuse, misuse and result in mixed reaction from learners [30]. Training is vital to adopting E-learning as literature also attests to this [23]. Lack of E-learning training in the Colleges of Education as well as the absence of comprehensive E-learning in-service programs by the GES for its staff implied low motivation for E-learning.

A well designed training module will eliminate such barriers and motivate the use of E-learning [32]; [6].

Training individuals in e-learning changes the negative perceptions militating against it and ultimately enhances its patronage. This relationship was in consonance with literature [10]; [15]; [11]; [22].

An interesting observation was the lack of statistical relationship between IT infrastructure availability and E-learning usage. This is could be due to lack of training, high cost, ignorance of existing platforms, prevention of students usage by teachers/school administration due to fear of damage. There are many well equipped computer laboratories in schools which are either underutilized or for aesthetic/decorative purpose due to the prevention of maintenance cost.

Contrary to expectation, motivation was found not to correlate with perception and E-learning usage in this study. It is also understandable that negative perception would solicit low E-learning usage. Literature suggest that usefulness, ease-of-use and self-efficiency were very important in the awareness of E-learning implementation [42]. The application of the Keller ARCs model based on four concepts: attention (A), relevance (R), confidence (C), and satisfaction (S) can be effective in motivating people with negative perception of E-learning. "Reference [26]" also asserted that content-leaner interaction, learner-learner interaction, and learner-teacher interaction are critical in motivating people in when implementing E-learning.

The regression analysis yielded some interesting results. The training of individuals can demoralize individuals engaging in e-learning due to poorly designed E-learning platforms. In addition to the continuing debate about the effectiveness of E-learning compared to other modes of instructional delivery, other significant skills of learners needs to be considered to motivate them. "Reference [19]" highlights four key categories of instructional features-content, immersion, interactivity, and communication- for promoting effective E-learning influence.

As described in the preceding paragraphs, the availability of IT infrastructure does not necessarily imply adoption or usage of E-learning platforms. "Reference [33]" reported that computers in classroom have 'mixed' impact on learning and that test result from 31 countries show no appreciable improvements in student achievement in certain subjects although huge investment in IT infrastructure was made. Distractions from social media, lack of guided research and project work.

Also, motivation could not statistically predict perception which in turn statistically failed to predict E-learning usage. As stated earlier in the discussion, perception of individuals towards E-learning adoption can be changed positively following theoretical motivation principles which in turn can eliminates psychological and social barriers for effective

\section{Conclusions}

The emergence of IT and the Internet has presented a complex web of challenges and opportunities for education. The effective and successful integration of ICT into the teaching and learning process largely depend on vital constructs such as e-learning perception, e-learning training, e-learning accessibility, and adoption of e-learning.

On e-learning perception, there are several factors such as staff and students' exposure; feelings; attitudes; knowledge; motivation; and values that influence e-learning platform usage. Active support of educational administrator can be an effective catalyst to shaping students' perception of e-learning. Respondents had a positive perception of e-learning.

On e-learning training, high level of computer experience was linked to greater use of web-based learning. It was found that computer literacy skills and e-learning usage were low due to lack of adequate training. ICT as a subject was introduced in the pre-tertiary educational curriculum less than a decade ago.

On accessibility to both IT infrastructure and e-learning platforms, the major mode of Internet access was mobile phone which has unstable and low bandwidth internet connectivity. Furthermore, most schools lacked fully furnished ICT laboratory for e-learning utilization by students. Also, knowledge of e-learning platforms and their usage were very limited.

Finally, there was no significant relationship between online hours spent by both staff and students and e-learning usage.

\section{Recommendations}

The study strongly recommends that following:

1. The GES in collaboration with second cycle schools should provide a reliable Internet facility and computer access to both students and staff.

2. Systematic training on e-learning should be organized for teachers and students to enhance the 
adoption and regular patronage of e-learning platforms in order to improve their educational output.

3. An e-learning department should be established under the ministry of education to develop comprehensive national e-learning platforms to serve as a complementary form of learning for students in formal education and as an educational option for people outside mainstream education.

4. Furthermore, classrooms and laboratories should be fully equipped to support the patronage of e-learning.

5. The ban on the use of portable computers by students in the second cycle schools should be lifted in order to encourage the use of mobile devices in accessing e-learning platforms.

\section{REFERENCES}

[1] Afshari, M., Bakar, K. A., Luan, W. S., Samah, B. A., \&Fooi, F. S. (2009). Factors affecting teachers' use of Information and Communication Technology. International Journal of Instruction, 2 (1), 78-98.

[2] Alemneh, D., \& Hastings, S. (2006). Developing the ICT infrastructure for Africa: Overview of barriers to harnessing the full power of the Internet. Journal of Education for Library and Information Science. 24 (1), 4-16.

[3] Alkharang, M. M., \& Ghinea, G. (2013). E-learning in Higher Educational Institutions in Kuwait: Experiences and Challenges. International Journal of Advanced Computer Science and Application, 4 (4).1-6.

[4] Ambrose, S., Bridges, M., DiPietro, M., Lovett, M., \& Norman, M. (2010). How Learning Works: Seven Research-Based Principles for Smart Teaching - chapter 3. San Francisco: John Wiley \& Sons.

[5] Blackmore, M., Stanley, N., Coles, D., Hodgkingson, K., Taylor, C., \& Vaughan, G. (1992). "A preliminary view of students' information technology experience across UK initial teacher training institutions," Journal of Information Technology for Teacher Education, 1 (2), 241-254.

[6] Brinkerhoff, J. (2006).Effects of a long-duration, professional development academy on technology skills, computer self-efficacy and technology integration beliefs and practices. Journal of Research on Technology in Education, vol. 39, no. 1, pp. 22-43.

[7] Bukaliya, R., \& Mubika, A. K. (2011). Teacher Competence in ICT: Implications for Computer Education in Zimbabwean Secondary Schools, International Journal of Social Sciences and Education.1 (4).

[8] Chowdhry, A. (2015). The Globe and Mail (n.d). Computers in Classroom have 'mixed' impact on learning: OECD report. Retrieved September 16, 2015, fromhttp://www.the globeandmail.com/news/national/education/computers-in-clas sroom-have mixed-impact-on-learning-oecd report/article 26373533/

[9] Clark, R. E. (1994). Media will never influence learning.
Educational Technology Research \& Development, 42(2), 21-29. Retrieved February 15, 2006, from http://www.usq.edu.au/material/unit/resource/clark/media.ht $\mathrm{ml}$

[10] Demirci, A. (2009). How do Teachers Approach New Technologies: Geography Teachers' Attitudes towards Geographic Information Systems (GIS). European Journal of Educational Studies, vol. 1, no.1.

[11] Drent, M., \& Meelissen, M. (2008). Which factors obstruct or stimulate teacher educators to use ICT innova-tively? Computers \& Education, vol.51, no.1, pp. 187-199.

[12] Edumadze, J. K. E., Ossie-Anto, T. A., Edumadze, G., Tamakloe, W. K., Asamoah, E., \& Boadi, E. (2014). Evaluating the Awareness and Perceptions of Lecturers in using E-Learning Tools for Teaching in University of Cape Coast. International Journal of Computing Academic Research. 3 (1), 1-11.

[13] Elgort, I. (2005). E-learning adoption: Bridging the chasm. [O nline].Available:http://ascilite.org.au/conferences/brisbane05/ blogs/proceedings/20_Elgort.pdf

[14] Galbreath, I. K. (2000). An analysis of the primary school teachers' usage of instructional software. International Journal of Emerging Technologies, 3(1), 45-53.

[15] Huang, H. M., \&Liaw, S. S. (2005). Exploring users’ attitudes and intentions toward the Web as a survey tool. Computers in Human Behavior, vol. 21, no. 5, pp.729-743.

[16] Igbaria, M., \&Chakrabarti, A. (1990). Computer anxiety and attitudes towards Microcomputer use. Behavior and Information Technology.

[17] Jan, P., Lu, H., \& Chou, T. (2012). The adoption of e-learning: an institutional theory perspective. The Turkish Online Journal of Educational Technology. 11(3).p 326-343.

[18] Kashima, T., Matsumoto, S. \& Ihara, T. (2011). Proposal of an e-Learning System with Skilled-based Homework Assignments. Retrieved on August 1, 2014 fromwww.iaeng.com.

[19] Kozlowski, S. W. J., \& Bell, B. S. (2007). A theory-based approach for designing distributed learning systems. In S. M. Fiore \& E. Salas (Eds.), Toward a science ofdistributed learning (pp. 15-39). Washington, DC: APA.

[20] Kozma, R. (1991). Learning with media. Review of Educational Research, 61(2), 179-211.

[21] Laudon, C., \&Laudon, P. (2012). Management Information Systems, (12 ${ }^{\text {th }}$ ed.). Pearson Education, Inc., Upper Saddle River, NJ: Prentice Hall.

[22] Lawless, K., \& Pellegrino, J. (2007). Professional development in integrating technology into teaching and learning: Knowns, unknowns and ways to pursue better questions and answers. Review of Educational Research, vol. 77, no. 4, pp. 575-614.

[23] Levin, T., \& Wadmany, R. (2008). Teachers’ views on factors affecting effective integration of information technology in classroom: Developmental scenery. Journal of Technology and Teacher Education, vol. 16, no. 2, pp. 233-236.

[24] [24] Martin, B. L., \& Briggs, L. J. (1986).The affective and cognitive domains: Integration for theory and research, Englewood Cliffs, NJ: Educational Technology. 
[25] Mitchell, T. J. F., Chen, S. Y., \& Macredie, R. D. (2005). The relationship between web enjoyment and student perceptions and learning using a web-based tutorial. Learning, Media and Technology, 30 (1), 27-40.

[26] Moore, M. G. (1989). Three Types of Interaction. American Journal of Distance Education 1. 3(2).

[27] Mueller, J., Wood, E., Willoughby, T., Ross, C., Specht, J. (2008). Identifying discriminating variables between teachers who fully integrate computers and teachers with limited integration. Computers and Education, 51, 1523-1537.

[28] Naidu,S. (2006). E-Learning: A Guidebook of Principles, Procedures and Practices. ( $2^{\text {nd }}$ ed.). Common wealth Educational Media Center for New Delhi, India.

[29] National Centre for Education Statistics (2000). Educational equity of girls and women. Washington, DC: US Depart ment of Education, NCES. NCES 2000-030.

[30] Nehme, M. (2010). E-Learning and Students’ Motivation, 20 Legal Education Review, 223-239, SSRN-id2347142, 2010. Retrieved from SSRN: http://ssrn.com/abstract=2347142

[31] Olson, J., Codde, J., deMaagd, K., Tarkelson, E., Sinclair, J., Yook, S., \& Egidio, R. (2011). An Analysis of e-Learning Impacts \& Best Practices in Developing Countries With Reference to Secondary School Education in Tanzania. Michigan State University Board of Trustees

[32] Sandholtz, J. H., \& Reilly, B. (2004). Teachers, not technicians: Rethinking technical expectations for teachers. Teachers College Record, 106(3), 487-512.

[33] OECD. (2015). Students, Computers and Learning: Making the

Connection.http://www.oecd.org/education/students-compute rs-and-learning-97 89264239555-en.htm

[34] Osguthrope, R. T. \& Graham, C. R. (2003). "BL systems: Definitions and directions” Quarterly Review of Distance
Education, 4(3), 227-234.

[35] Roblyer, M. D. (2006). Integrated education technology into teaching $\left(4^{\text {th }}\right.$ ed.). Upper Saddle River, NJ: Pearson Prentice Hall.

[36] Romiszowski, A. (2004). How's the e-learning baby? Factors leading to success or failure of an educational technology innovation, Educational Technology44 (1), January-February, 5-27.

[37] Russell, G., \& Bradley, G. (1997). Teachers' computer anxiety: Implications for professional development. Education and Information Technologies, vol. 2, pp.17-30.

[38] The Ghana ICT for Accelerated Development (ICT4AD) Policy (2003). [Online]. Available: www.nita.gov.gh/system/files/nita_resource/Ghana_ICT4AD _Policy.pdf

[39] UNESCO. (2007) ICT in Teacher Education: Case Studies from the Asia-Pacific Region. Bangkok: UNESCO. [Online]. Available: http://unesdoc.unesco.org/images/0015/001567/1567 57e.pdf

[40] Wheeler, S. (2005). Transactional Distance and Student Support in Distance Education. EDEN 2005 Conference: Helsinki University of Technology.

[41] White, C. (2005). Contribution of distance education to the development of individual learners. Distance Education, 26 (2), 165-181.

[42] Yacob, A., Kadir, A. Z. A., Zainudin, O., \&Zurairah, A. (2012). Student Awareness towards E-Learning in Education. Procedia-Social and Behavioral Sciences, 67, 93-10. http://dx.doi.org/10.1016/j.sbspro.2012.11.310.

[43] Yildirim, S. (2007). "Current Utilization of ICT in Turkish Basic Education Schools: A Review of Teacher's ICT Use and Barriers to Integration”. International Journal of Instructional Media, vol. 34, no.2, pp.171-86. 